\title{
THERMOGRAPHY APPLIED TO THE EFFICENCY DEVELOPMENT OF UTILISATION OF THE ENERGY IN THE BUILDING ENERGETICS
}

\author{
TATIANA TOMA, VALENTINA BARBU, SERBAN NOVAC
}

\section{Abstract}

The advent and the liberation of energy market induce new problems for the electrical and thermal energy consumers. One of these problems are the one for reducing the energetic input and to respect the conditions that are imposed by laws who regulate the growing of energy efficiency.

The social politic regarding the environment quality and the building in harmony with the nature views also the quality of the comfort.

At once with the consumer pretensions increase, which are irreversible, the expert chich is dealing with the insurance of the thermic comfort is obliged to take therefore the measures resorting to: the procurement of the performance machines and equipments; the establishment of some solutions suitable with the building type; a new conception regarding the execution of the installation working and the insurance of the efficient exploitation by automatic command; reduced consumption of energy.

This paper present the utilization of thermofraphy applied in building energetic. 
http://dx.doi.org/10.21611/qirt.2008.05_08_08 